\title{
TINGKAT PENCEMARAN DETERJEN PADA SEDIMEN MENGGUNAKAN INDIKATOR KIMIA-BIOLOGI DI SUNGAI SAYUNG
}

\author{
Dwi Santi Putri, Pujiono Wahyu Purnomo, Haeruddin ${ }^{1}$
}

Program Studi Manajemen Sumberdaya Perairan, Jurusan Perikanan

Fakultas Perikanan dan Ilmu Kelautan, Universitas Diponegoro

\begin{abstract}
ABSTRAK
Dewasa ini tingkat pencemaran air mengalami peningkatan secara tajam seiring dengan peningkatan jumlah penduduk. Zat pencemar yang berasal dari deterjen ini masuk ke lingkungan perairan dan akan tersebar ke air, terabsorsi oleh biota laut serta terakumulasi dalam sedimen. Oleh karena itu perlunya penelitian tentang tingkat pencemaran deterjen pada sedimen mengunakan indikator kimia dan biologi. Tujuan dari penelitian ini antara lain mengetahui konsentrasi deterjen didalam sedimen, KR dan H' makrozoobentos, mengkaji hubungan antara konsentrasi deterjen didalam sedimen dengan kelimpahan individu makrozoobentos dan menentukan tingkat pencemaran sedimen berdasarkan konsentrasi deterjen dan struktur komunitas makrozoobentos. Penelitian ini menggunakan metode survey dengan teknik penentuan lokasi pengambilan sampel Purposive sampling. Sampling dilakukan dua kali dengan 2 kali pengulangan. Pengukuran konsentrasi deterjen dalam sedimen, identifikasi makrozoobentos Setelah dilakukan identifikasi dan penghitungan jumlah spesies, selanjutnya dilakukan perhitungan nilai Kelimpahan individu dan Kelimpahan Relatif (KR), Indeks Keanekaragaman (H'), Indeks Keseragaman (e), serta Indeks Dominasi (D). Hasil nilai konsentrasi deterjen pada sampling I dan II yaitu stasiun 1 berkisar $0,18-5,53 \mathrm{mg} / \mathrm{kg}$, stasiun 2 berkisar 47,21 - 123,17 mg/kg, stasiun 3 berkisar 2,30-5,50 mg/kg, stasiun 4 0,02-0,96 mg/kg. Nilai KR pada stasiun 1 sampling I dan II adalah 87\% dan 94\%; stasiun 2 sampling I dan II adalah 97\% dan 98\%; stasiun 3 sampling I dan II adalah 88\%, dan 82\%; stasiun 4 sampling I dan II adalah $46 \%$ dan $43 \%$. Nilai H' stasiun 1 sampling I dan IIadalah 0,44 dan 0,25; stasiun 2 sampling I dan II adalah 0,14 dan 0,09; stasiun 3 sampling I dan II adalah 0,51 dan 0,49; stasiun 4 sampling I dan II adalah 1,49 dan 1,28. Kesimpulan yang didapat yaitu sedimen sungai Sayung tercemar oleh deterjen, struktur komunitas makrozoobentos dengan melihat indeks keanekaragaman berkisar 0,14 - 1,49 yang menunjukkan bahwa kemampuan perairan sungai Sayung untuk mendukung kelangsungan hidup makrozoobentos tergolong rendah dan dilihat kondisi kestabilan suatu komunitas dalam keadaan tidak stabil.
\end{abstract}

Kata kunci: Deterjen, Struktur komunitas makrozoobentos, Tingkat pencemaran sedimen

\section{ABSTRACT}

Recently, the level of water pollution has increased sharply in line with the number of population. Contaminants derived from the detergent blown into the water, spread, and absorb by marine biotic and will be accumulate in sediment. Therefor need a research to measure the level of detergent contaminant in sediments by using chemical and biological indicators. The purpose of this research is to know concentration of detergent in sediments, to know KR and H' macrozoobentos, examines relationship between detergent concentration in sediments with of Individuals abudance makrozoobentos and determine level of pollution of sediments based on concentrations of detergent and makrozoobentos community structure. This study uses the technique of determining location survey sampling with purposive sampling. Meanwhile, the sampling was conducted in two repetitions. First, measured detergent concentration in sediment and then identified macrozoobentos. After all, count the number of species, then performed the calculation of Individuals abudance and Relative Abundance (KR), Diversity Index $\left(\mathrm{H}^{\prime}\right)$, uniformity index $(\mathrm{E})$, as well as the dominance index (D). Detergent concentration values obtained results I and II, on station 1 ranged from 0,18 to $5,53 \mathrm{mg} / \mathrm{kg}$, on stations 2 ranged from 47,21 to $123,17 \mathrm{mg} / \mathrm{kg}$, stations 3 ranged from 2,30 to $5,50 \mathrm{mg} / \mathrm{kg}$, stations 4 ranged from 0,02 to $0,96 \mathrm{mg} / \mathrm{kg}$. KR value in station 1 with sampling I and II has a result $87 \%$ and $94 \%$; in station $2 \mathrm{KR}$ value were $97 \%$ and $98 \%$, in station $3 \mathrm{KR}$ value were $88 \%$ and $82 \%$, in station 4 KR Value were $46 \%$ and $43 \%$. H' value on station 1 with sampling I was 0,44 and sampling II was $0,25, \mathrm{H}^{\prime}$ value on station 2 with sampling I was 0,14 and sampling II was 0,09 , H' value on station 3 with sampling I was 0,51 and sampling II was $0,49, \mathrm{H}^{\prime}$ value on station 4 with sampling I was 1,49 and sampling II was 1.28 . The conclusion of this research are sediment contaminated by detergent, macrozoobentos community structure at the diversity index ranged from 0,14 to 1,49 indicated that waters of the Sayung river ability to support survival of macrozoobentos were low and condition of the community in an unstable state.

Keywords: Detergent, Macrozoobentos community structure, Sediment pollution level 


\section{Pendahuluan}

Air merupakan kebutuhan utama bagi mahluk hidup. Air yang dibutuhkan adalah air bersih dan sehat yaitu air yang tidak mengandung bibit penyakit dan bahan kimia yang beracun. Dalam kehidupan sehari-hari manusia menggunakan air untuk berbagai keperluan seperti minum, mencuci, industri, perikanan (baik sebagai hunian ikan maupun budidaya ikan atau biota air), pertanian dan lain sebagainya (Darmono, 2001).

Sungai Sayung merupakan sungai yang terletak di Kecamatan Sayung Kebupaten Demak yang sepanjang daerah alirannya telah banyak dimanfaatkan untuk berbagai kegiatan seperti untuk mencuci, pariwisata dan sebagai mata pencaharian nelayan kecil sekitar yang pekerjaanya tidak tetap yaitu mencari ikan untuk dikonsumsi dan dijual di tempat Wisata Bahari Morosari.

Limbah kegiatan domestik dapat meningkatkan kandungan bahan organik, lemak-minyak di dalam perairan serta bahan non-organik yang sulit terdegradasi seperti deterjen. Dewasa ini tingkat pencemaran air mengalami peningkatan secara tajam seiring dengan peningkatan jumlah penduduk. Pencemaran air dapat disebabkan oleh berbagai hal, salah satunya adalah akibat adanya limbah deterjen. Produk deterjen saat ini sudah digunakan oleh hampir semua orang untuk berbagai keperluan seperti mencuci pakaian dan perabotan serta sebagai bahan pembersih. Sepanjang sungai sayung dipadati pemukiman penduduk, sungai Sayung biasa dipergunakan sebagai tempat pembuangan limbah domestik terlihat dari fisik sungai yang tidak sedikit sampah dan limbah masuk ke badan sungai, salah satunya pembuangan deterjen.

Deterjen merupakan bahan pembersih yang umum digunakan oleh usaha industri ataupun rumah tangga. Produksi deterjen terus meningkat setiap tahunnya untuk memenuhi kebutuhan masyarakat akan bahan pembersih (Connel dan Miller, 1995). Zat pencemar yang berasal dari deterjen ini masuk ke lingkungan perairan dan akan tersebar ke air, terabsorsi oleh biota laut serta terakumulasi dalam sedimen.

Sungai Sayung merupakan media hidup beraneka organisme akuatik yang mempunyai batas toleransi tertentu terhadap bahan pencemar. Salah satu hewan yang sensitif terhadap perubahan kualitas lingkungan perairan adalah makrozoobentos. Dengan upaya tersebut, maka makrozoobentos digunakan sebagai indikator biologi tingkat pencemaran karena sifat hidupnya menetap atau pergerakanya sangat lambat di permukaan atau dalam substrat perairan. Beberapa jenis organisme makrozoobentos mempunyai daya tahan tinggi terhadap kualitas air yang jelek sehingga organisme tersebut dapat digunakan sebagai indikator kualitas air suatu perairan (Wilhm, 1975). Perubahan komunitas makrozoobentos secara umum disebabkan oleh masuknya bahan organik, bahan kimia beracun dan perubahan substrat dasar (APHA, 1992).

Dengan mempertimbangkan fenomena tersebut, maka di wilayah penelitian yaitu di sungai Sayung diperkirakan terjadi tumpang tindih kepentingan. Pertama terjadinya peningkatan deterjen terakumulasi di sedimen, kedua akibat akumulasi di dasar perairan dapat memberikan dampak negatif terhadap biota makrozoobentos. Oleh karena itu perlunya penelitian tentang tingkat pencemaran deterjen pada sedimen mengunakan indikator kimia dan biologi. Kimia ditinjau dari konsentrasi deterjen dalam kandungan sedimen dan biologi ditinjau kelimpahan dan keanekaragaman makrozoobentos.

Tujuan dilakukannya penelitian ini adalah sebagai berikut:

1. Mengetahui konsentrasi deterjen didalam sedimen;

2. Kelimpahan relatif dan indeks keanekaragaman makrozoobentos;

3. Mengkaji hubungan antara konsentrasi deterjen didalam sedimen dengan kelimpahan individu makrozoobentos;

4. Menentukan tingkat pencemaran sedimen berdasarkan konsentrasi deterjen dan struktur komunitas makrozoobentos.

Penelitian ini dilaksanakan pada bulan Maret - April 2013 di Sungai Sayung, Kecamatan Sayung, Kabupaten Demak, Jawa Tengah. Hasil dari penelitian ini diharapkan dapat menjadi sumber pengetahuan bagi masyarakat dan pemerintah untuk lebih memahami status pencemaran sungai Sayung oleh deterjen dengan indikator makrozoobentos agar masyarakat sekitar lebih peduli untuk menjaga kebersihan lingkungan dan pertimbangan dalam upaya mengatasi pencemaran lingkungan yang diakibatkan oleh air limbah deterjen khususnya di sungai Sayung.

\section{Materi dan Metode Penelitian}

\section{A. Materi Penelitian}

Materi yang digunakan dalam penelitian ini adalah sedimen yang terdapat di perairan sungai Sayung. Alat dan bahan yang digunakan dalam penelitian ini yaitu Ekman Grab untuk mengambil sampel sedimen dan makrozoobentos. Saringan bentos untuk menyaring makrozoobentos. Kantong plastik untuk tempat sedimen. Botol sampel untuk menyimpan sampel makrozoobentos. Formalin $4 \%$ untuk mengawetkan makrozoobentos. Rose bengale untuk mewarnai sampel biota. Aquades untuk membersihkan biota dari subtract. Kamera digital digunakan sebagai alat untuk mendokumentasikan kegiatan. Peralatan lain yang digunakan adalah current meter, secchi disk, botol sampel, DO meter, termometer, pH paper, salinorefrakto meter, stopwatch, GPS, kertas label, lup, pipet tetes, mikroskop, ember, cetok. 


\section{B. Metode Penelitian}

Metode yang digunakan dalam penelitian ini adalah metode Survei, menurut Kerlinger (1973) dalam Sugiono (2005), penelitian survei adalah penelitian yang dilakukan pada populasi besar maupun kecil, tetapi data yang dipelajari adalah data dari sampel yang diambil dari populasi tersebut, sehingga ditemukan kejadian-kejadian relatif, distribusi, dan hubungan-hubungan antar variabel.

\section{Penentuan Lokasi Pengambilan Sampel}

Penentuan lokasi pengambilan sampel yaitu contoh sedimen dan makrozoobentos pada 3 lokasi pengambilan sampel, ditentukan berdasarkan purposive sampling. Purposive sampling adalah teknik penentuan sampel dengan pertimbangan tertentu, yaitu berdasarkan letak lokasi pengambilan sampel dari sumber pencemarannya, yaitu upper stream, middle stream dan lower stream. Pada setiap lokasi sampling dibagi menjadi 2 sub stasiun dan tiap sub stasiun dibagi lagi menjadi 3 titik (pinggir, tengah, pinggir), pengambilan sampel sedimen dikomposit menjadi 1 sampel setiap sub stasiun, pengambilan makrozoobentos diambil pertitik. kemudian dilakukan 2 kali perlakuan pengambilan sampel yaitu pada saat sungai pasang dan surut.

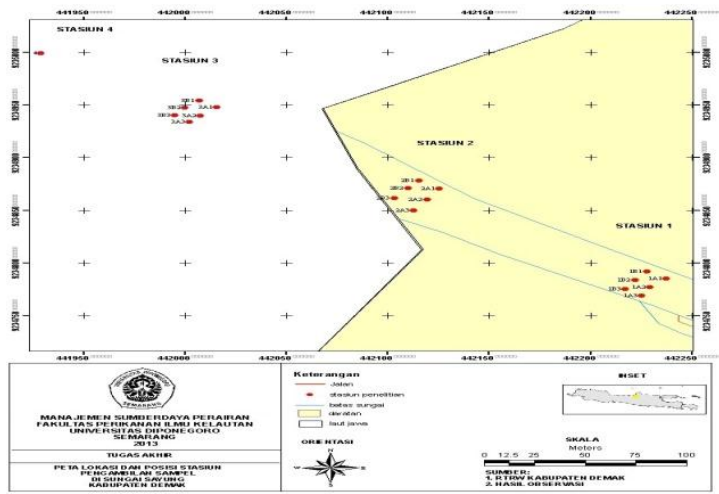

Gambar 1. Peta Lokasi dan Stasiun Pengambilan Sampel di Perairan Sungai Sayung

\section{Pengukuran Parameter Kualitas Air}

Arus diukur menggunakan current meter; Kecerahan dan kedalaman diukur dengan menggunakan Secchi disk; Temperatur dan oksigen terlarut diukur menggunakan DO meter; pH di ukur dengan menggunakan kertas lakmus; Salinitas diukur menggunakan salinorefrakto meter.

\section{Pengambilan Sampel Makrozoobentos}

Pengambilan makrozoobentos menggunakan Ekman Grab dengan bukaan $22,5 \mathrm{~cm} \times 22,5 \mathrm{~cm}$. Sampel yang diperoleh kemudian disaring menggunakan saringan bentos dengan mesh size 0,5x0,5 $\mathrm{mm}$. Makrozoobentos dipisahkan dari kotoran yang masih menempel diayakan dengan pembilasan yang dilakukan dari bawah saringan. Kemudian dimasukan dalam botol sampel, diawetkan dengan formalin $4 \%$ dan ditetesi 2-3 tetes Rose Bengale. Sampel kemudian dicuci dengan air bersih dan ditempatkan ke dalam baki yang cerah untuk dilakukan penyortiran lagi dan dibilas sekali lagi. Prosedur pengambilan makrozoobentos dilakukan berdasarkan sumber buku ajar identifikasi Avertebrata Air. Kemudian dilakukan identifikasi menggunakan lup dan mikroskop, serta buku identifikasi Dharma B. (1988), Siput dan Kerang Indonesia (Indonesian Shells); (1992), Indonesian Shells II dan (2007), buku ajar identifikasi mata kuliah Avertebrata Air.

\section{Pengambilan Sampel Sedimen}

Pengambilan sampel sedimen diambil dengan menggunakan cetok kemudian dikompositkan di ember setelah itu dimasukan ke dalam plastik berukuran $1 \mathrm{~kg}$.

\section{Pengukuran Deterjen dalam Sedimen}

Pengukuran deterjen dalam sedimen dilakukan di laboratorium BPIK (Balai Pengujian dan Informasi Konstruksi) dengan menggunakan metode analisis laboratorium dilaksanakan menurut Standar Nasional Indonesia (SNI) cara uji kadar surfaktan anionik dengan spektrofotometer secara biru metilen

\section{Analisis Data}

Setelah dilakukan identifikasi dan penghitungan jumlah spesies, selanjutnya dilakukan perhitungan nilai Kepadatan dan Kelimpahan Relatif (KR), Indeks Keanekaragaman (H'), Indeks Keseragaman (E), serta Indeks Dominasi (D) sebagai berikut:

\section{Kelimpahan individu dan Kelimpahan Relatif.}

Kelimpahan individu makrozoobentos didefinisikan sebagai jumlah individu makrozoobentos per satuan luas $\left(\mathrm{m}^{2}\right)$. Makrozoobentos yang telah diidentifikasi akan dihitung kepadatannya berdasarkan jenis yang ditemukan dengan rumus Krebs (1972):

$$
K=\frac{10.000 \times a}{b}
$$




\section{Dimana:}

K : Kepadatan makrozoobentos (individu/m2)

a : Jumlah Makrozoobentos (individu)

b : luas bukaan Ekman Grab $(22,5 \mathrm{~cm} \times 22,5 \mathrm{~cm})$

$10.000 \quad$ : konversi dari $\mathrm{cm}^{2}$ menjadi $\mathrm{m}^{2}$

Menghitung kelimpahan individu dan relatif dengan menggunakan formula Brower et al (1989), maka menggunakan rumus sebagai berikut :

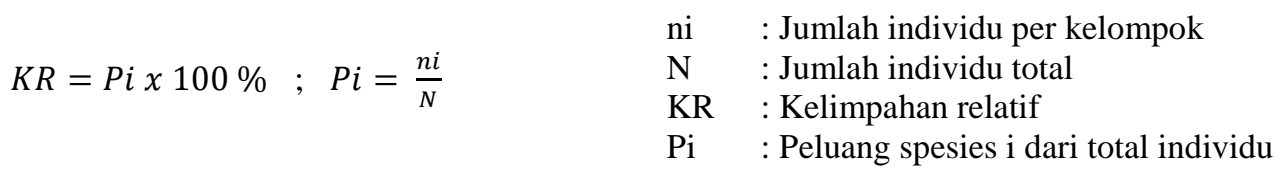

Dimana:

\section{Indeks keanekaragaman}

Indeks Keanekaragaman (H') dihitung dengan menggunakan formulasi Shannon-Wiener (Pieolu 1966 dalam Odum 1971), yaitu:

$$
H^{\prime}=-\sum_{i=s}^{s} P i \ln P i
$$

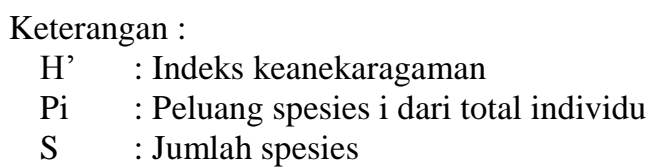

Brower et al. (1990) kisaran nilai Indeks Keanekaragaman dapat diklasifikasikan sebagai berikut :

- $\quad \mathrm{H}^{\prime}<3.32$ = keanekaragaman rendah, penyebaran jumlah individu tiap spesies rendah dan kestabilan komunitas rendah.

- $\quad 3.32<\mathrm{H}^{\prime}<9.96$ = keanekaragaman sedang, penyebaran individu tiap spesiesnya sedang dan kestabilan komunitas sedang.

- $\quad \mathrm{H}^{\prime}>9.96$ = keanekaragaman tinggi, penyebaran jumlah individu tiap spesies tinggi dan kestabilan komunitas tinggi.

\section{Indeks keseragaman}

Untuk menghitung keseragaman jenis dengan menggunakan rumus Indeks Evennes (Odum, 1971), yaitu:

$$
E=\frac{H^{\prime}}{H \operatorname{Hax}} \quad \begin{aligned}
& \text { Dimana : } \\
& \mathrm{E}=\text { Keseragaman jenis } \\
& \mathrm{S}=\text { Jumlah spesies } \\
& \mathrm{H} \max =\text { Ln S }
\end{aligned}
$$

\section{Indeks dominasi (D)}

Menurut Odum (1971), untuk menghitung indeks dominasi maka digunakan rumus sebagai berikut :

$$
D=\left(\frac{n i}{N}\right)^{2}
$$

\section{Keterangan :}

D : Indeks dominasi

ni : Jumlah individu spesies

$\mathrm{N} \quad$ : Jumlah total individu spesies

\section{Evaluasi Data}

Hubungan antara konsentrasi deterjen didalam sedimen terhadap komunitas makrozoobentos dilakukan dengan menggunakan analisis Regresi. Untuk menguji ketepatan fungsi (goodness of fit test) yang digunakan dilakukan perbandingan terhadap nilai $\mathrm{R}^{2}$, semakin besar nilainya (mendekati 1) makin bagus untuk meramalkan. Pengujian menggunakan Regresi Linier diperoleh nilai $\mathrm{R}^{2}$ yang sangat kecil. Nilai $\mathrm{R}^{2}$ tertinggi diperoleh pada persamaan Regresi Kuadratik.

Persamaan Regresi Kuadratik:

$$
\mathrm{Y}=\mathrm{B}_{0}+\mathrm{B}_{1} \mathrm{X}+\mathrm{B}_{2} \mathrm{X}^{2}+\ldots \ldots \ldots \ldots+\mathrm{B}_{\mathrm{k}} \mathrm{X}_{\mathrm{k}}
$$

dimana:

$\mathrm{Y}=$ Variabel tetap, $\mathrm{X}=$ Variabel bebas

Arti nilai korelasi tersebut Sudjana, (1982):

\begin{tabular}{ll}
\hline Nilai Koefisien Korelasi & Keterangan \\
\hline $0,00-1,199$ & Sangat rendah \\
$0,120-0,399$ & Rendah \\
$0,40-0,599$ & Cukup \\
$0,60-0,799$ & Kuat \\
$0,80-1,000$ & Sangat kuat \\
\hline
\end{tabular}




\section{Hasil dan Pembahasan}

\section{Deskripsi lokasi Penelitian}

Lokasi penelitian di perairan sungai Sayung adalah $06^{\circ} 56^{\prime}$ LS- $06^{\circ} 55^{\prime}$ LS dan $110^{\circ} 29^{\prime}$ BT- $110^{\circ} 28^{\prime}$ BT. Batas-batas sebelah utara adalah Laut Jawa, sebelah timur kecamatan Karang tengah, sebelah selatan kecamatan Mranggen, sebelah barat kecamatan Genuk (kota semarang) terdiri dari 20 desa yaitu 10 desa di jalan pantura dan 10 desa di sebelah selatan jalan pantura dengan luas wilayah $78,80 \mathrm{~km}^{2}$. Aktivitas-aktivitas yang ada di Sayung adalah pemukiman dan pariwisata. Pemukiman paling mendominasi sehingga yang perlu ditinjau dalam penelitian ini adalah limbah hasil akitivitas penduduk Sayung yang menghasilkan limbah deterjen. Limbah deterjen ini nantinya akan mencemari lingkungan perairan pada sungai Sayung, sehingga akan berakibat pada biota perairan khususnya makrozoobentos.

\section{Konsentrasi Deterjen}

Konsentrasi deterjen dalam sedimen di perairan sungai Sayung dapat dilihat di tabel 1.

Tabel 1. Konsentrasi Deterjen dalam Sedimen

\begin{tabular}{cccc}
\hline \multirow{2}{*}{ Stasiun } & Sub stasiun & \multicolumn{2}{c}{ Deterjen $(\mathrm{mg} / \mathrm{kg})$} \\
\cline { 3 - 4 } & & Sampling I & Sampling II \\
\hline 1 & 1A & 4,35 & 5,53 \\
& 1B & 0,18 & 0,89 \\
& 2A & 120,94 & 123,17 \\
3 & 2B & 47,21 & 55,04 \\
& 3A & 5,50 & 4,54 \\
4 & 3B & 2,30 & 3.68 \\
& LAUT & 0,02 & 0,96 \\
\hline
\end{tabular}

Struktur Komunitas Makrozoobentos

Struktur komunitas makrozoobentos di setiap stasiun dapat dilihat di tabel berikut:

Tabel 2. Struktur Komunitas Makrozoobentos

\begin{tabular}{lcccccccc}
\hline & \multicolumn{2}{c}{ Stasiun 1 } & \multicolumn{2}{c}{ Stasiun 2 } & \multicolumn{2}{c}{ Stasiun 3 } & \multicolumn{2}{c}{ Stasiun 4 } \\
\cline { 2 - 8 } & \multicolumn{2}{c}{ Sampling } & \multicolumn{2}{c}{ Sampling } & \multicolumn{2}{c}{ Sampling } & \multicolumn{2}{c}{ Sampling } \\
\cline { 2 - 8 } & I & II & I & II & I & II & I & II \\
K & $34.844,8$ & $39.091,4$ & $12.128,4$ & $11.891,4$ & $4.898,77$ & 12.563 & 296,30 & 138,27 \\
H' & 0,44 & 0,25 & 0,14 & 0,09 & 0,51 & 0,49 & 1,49 & 1,28 \\
E & 0,31 & 0,18 & 0,20 & 0,12 & 0,29 & 0,36 & 0,83 & 0,92 \\
D & 0,75 & 0,88 & 0,94 & 0,97 & 0,77 & 0,67 & 0,04 & 0,18 \\
\hline
\end{tabular}

\section{Struktur Komunitas Makrozoobentos Stasiun 1}

Kelimpahan Relatif (KR) dan Indeks Dominasi (D)

Berdasarkan pengamatan diperoleh data untuk stasiun 1 sampling I yaitu Terebralia palustris $87 \%$, Faunus ater 12\%, Nereidae 1\%, Capitellidae 0\%. Kelimpahan relatif tertinggi adalah Terebralia palustris sebesar $49 \%$ dan terendah Capitellidae $0 \%$.

Nilai indeks dominasi dari stasiun 1 sampling I kelas Gastropoda yaitu Terebralia palustris 0,846, Faunus ater 0,21, kelas Polychaeta yaitu Nereidae 0,002, Capitellidae 2,08x10-6.

\section{Struktur Komunitas Makrozoobentos Stasiun 2}

Kelimpahan Relatif (KR) dan Indeks Dominasi (D)

Pengamatan stasiun 2 sampling II diperoleh data kelimpahan relatif masih sama dengan sampling I yaitu Terebralia palustris $98 \%$ dan Faunus ater $2 \%$.

Nilai indeks dominasi dari stasiun 2 sampling I kelas Gastropoda yaitu Terebralia palustris 0,94 sampling ke II yaitu 0,97, Faunus ater 0,00096 sampling ke II yaitu 0,00027.

\section{Struktur Komunitas Makrozoobentos Stasiun 3}

Kelimpahan Relatif (KR) dan Indeks Dominasi (D)

Stasiun 3 sampling I diperoleh data Terebralia palustris 88\%, Terebralia scabra 8\%, Faunus ater 2\%, Marcia sp. 1\%, Anadara granosa 1\%, Capitellidae 0\%. Stasiun 3 sampling II diperoleh data KR kelas Gastropoda yaitu Terebralia palustris $82 \%$, Terebralia scabra 18\%, kelas Bivalvia yaitu Tellina albinela $0 \%$ dan kelas Polychaeta yaitu Nereidae 0\%.

Nilai indeks dominasi dari stasiun 3 sampling I kelas Gastropoda yaitu Terebralia palustris 0,77,

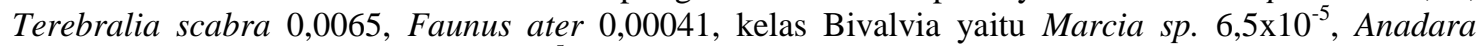
granosa 0,00015 , Capittelidae $1,6 \times 10^{-5}$ sampling ke II yaitu Gastropoda yaitu Terebralia palustris 0,67 , Terebralia scabra 0,03 , Tellina albinela $2,4 \times 10^{-6}$, kelas Polychaeta yaitu Nereidae $2,4 \times 10^{-6}$. 


\section{Struktur Komunitas Makrozoobentos Stasiun 4}

Kelimpahan Relatif (KR) dan Indeks Dominasi (D)

Kelimpahan relatif stasiun 4 atau stasiun yang berlokasi laut sampling I ini dari kelas Bivalvia $T$. platam 46\%, Gravarium granosa 20\%, Anadora granosa 13\%, Cerethidae 7\%, kelas Polychaeta yaitu Glyceridae 7\%, kelas Echinodermata Ophiuroidae 7\%.

Nilai indeks dominasi dari stasiun 4 sampling I yaitu kelas Bivalvia diantaranya Anadora granosa 0,02, Gravarium divericatum 0,04, T. Platam 0,22, Cerethidae 0,0044, kelas Polychaeta yaitu Syllidae 0,004, kelas Echinodermata yaitu Ophiuroidae 0,004. Nilai indeks dominasi stasiun 4 sampling II yaitu kelas Gastropoda yaitu Neritina turrita 0,02, Rhinoclavis sp. 0,18, kelas Bivalvia Gravarium divericatum 0,02, Tellina sp. 0,09.

\section{Parameter Kualitas Air}

Parameter kualitas air pada sampling I dan II dapat dilihat pada tabel berikut :

Tabel 3. Parameter Kualitas Air Sampling I

\begin{tabular}{lcccccccc}
\hline & \multicolumn{9}{c}{ Sampling I } & \multicolumn{2}{c}{ Stasiun 3 } & \multicolumn{2}{c}{ Stasiun 4 } \\
\cline { 2 - 8 } Parameter & \multicolumn{2}{c}{ Stasiun 1 } & \multicolumn{2}{c}{ Stasiun 2 } & Stan \\
Kualitas Air & $\bar{x}$ & SD & $\bar{x}$ & SD & $\bar{x}$ & SD & $\bar{x}$ & SD \\
\hline Kecerahan $(\mathrm{cm})$ & 15,4 & 4,33 & 13,08 & 4,16 & 26,17 & 4,80 & - & - \\
Kedalaman(cm) & 78,83 & 19,08 & 71,67 & 15,39 & 83,17 & 7,76 & - & - \\
Arus $(\mathrm{cm} / \mathrm{s})$ & 3,47 & 3,08 & 1,62 & 0,70 & 2,73 & 0,98 & - & - \\
Temperatur $\left({ }^{\circ} \mathrm{C}\right)$ & 29,67 & 0,20 & 30,95 & 0,18 & 31,10 & 0,54 & - & - \\
pH & 7 & 0 & 6,17 & 0,4 & 8 & 0 & - & - \\
Salinitas (\%o) & 0 & 0 & 0 & 0 & 6,5 & 1,64 & - & - \\
DO (mg/l) & 4,77 & 0,21 & 4,73 & 0,14 & 4,45 & 0,21 & - & - \\
\hline
\end{tabular}

Tabel 4. Parameter Kualitas Air Sampling II

\begin{tabular}{|c|c|c|c|c|c|c|c|c|}
\hline \multirow{3}{*}{$\begin{array}{l}\text { Parameter } \\
\text { Kualitas Air }\end{array}$} & \multicolumn{6}{|c|}{ Sampling II } & \multirow{2}{*}{\multicolumn{2}{|c|}{ Stasiun 4}} \\
\hline & \multicolumn{2}{|c|}{ Stasiun 1} & \multicolumn{2}{|c|}{ Stasiun 2} & \multicolumn{2}{|c|}{ Stasiun 3} & & \\
\hline & $\bar{x}$ & SD & $\bar{x}$ & SD & $\bar{x}$ & SD & $\bar{x}$ & SD \\
\hline Kecerahan $(\mathrm{cm})$ & 33,42 & 7,70 & 26,5 & 8,33 & 28,67 & 5,53 & - & - \\
\hline Kedalaman(cm) & 100,83 & 9,17 & 111,33 & 10.80 & 85,33 & 22,42 & - & - \\
\hline Arus $(\mathrm{cm} / \mathrm{s})$ & 6,37 & 4,37 & 2,2 & 2,52 & 5,32 & 2,71 & - & - \\
\hline Temperatur $\left({ }^{\circ} \mathrm{C}\right)$ & 29,3 & 0,09 & 30,57 & 0,05 & 31,18 & 0.15 & - & - \\
\hline $\mathrm{pH}$ & 7 & 0 & 6,17 & 0,4 & 8 & 0 & - & - \\
\hline Salinitas (\%o) & 0 & 0 & 0 & 0 & 8 & 1,10 & - & - \\
\hline DO (mg/l) & 4,9 & 0,4 & 4,68 & 0,32 & 5,02 & 0,51 & - & - \\
\hline
\end{tabular}

\section{Kecerahan}

Nilai kecerahan sangat dipengaruhi oleh keadaan cuaca, waktu pengukuran, kekeruhan dan padatan tersuspensi, serta ketelitian orang yang melakukan pengukuran (Effendi, 2003).

\section{Kedalaman}

Data kedalaman ini sangat bervariasi, data kedalaman cenderung lebih dalam saat sampling ke II dibanding sampling I ini dikarenakan saat sampling kedua pada sungai Sayung terjadi kondisi pasang sehingga kenaikan air meningkat menjadikan nilai kedalaman pada sampling II lebih dalam dibanding sampling sebelumnya.

Arus

Nilai rata-rata arus saat sampling I lebih kecil dibanding saat sampling ke II disebabkan faktor alam saat sampling pertama air lebih tenang dibanding saat sampling ke II tingginya pasang mempengaruhi arus. Ini sependapat dengan Barus (2002) dalam Nugrah (2008), arus berperan penting dalam penyebaran organisme, gas-gas terlarut dan pengangkutan substansi yang terdapat dalam air. Kecepatan arus sangat berfluktuasi dari waktu ke waktu tergantung dari fluktuasi debit, aliran air dan kondisi substrat yang ada. Nilai arus stasiun 2 selalu lebih kecil dibanding nilai arus stasiun lainnya, ini dikarenakan stasiun 2 merupakan tempat bertemunya aliran dari stasiun 1 dan aliran pasang stasiun 3 dan 4 sehingga titik temu arus berada pada stasiun 2 .

\section{Temperatur}

Perubahan temperatur yang terjadi diduga lebih disebabkan karena waktu pengukuran menentukan perubahan temperatur pada suatu perairan akan tetapi perubahan suhu tidak begitu berubah. Sampling I dilakukan lebih pagi dibanding sampling ke II kemudian pola temperatur ekosistem air dipengaruhi oleh beberapa faktor seperti intensitas cahaya matahari, perubahan musim, pertukaran panas antara air dengan udara sekelilingnya, ketinggian geografis, penutupan oleh vegetasi (Barus, 2002 dalam Nugrah, 2008). 


\section{Derajat Keasaman (pH)}

Dari hasil penelitian diperoleh nilai $\mathrm{pH}$ rata-rata sampling I dan II $7 \pm 0$ untuk stasiun 1 . Stasiun Nilai pH stasiun 3 sampling I dan II yaitu $8 \pm 0$, sedang stasiun 4 nilai pH baik sampling I dan ke II yaitu 9 . Nilai $\mathrm{pH}$ rata-rata berkisar 6 bersifat asam ini menandakan bahwa keanekaragaman bentos sedikit menurun terlihat juga data dari H' makrozoobentos jumlah spesiesnya kecil sesuai pernyatan Effendi (2003), bahwa nilai $\mathrm{pH}$ 6,0 - 6,5 berpengaruh umum terhadap keanekaragaman plankton dan bentos sedikit menurun. Apabila nilai $\mathrm{pH}$ air kurang dari 5,0 atau lebih besar dari 9,0 maka perairan itu sudah tercemar berat sehingga kehidupan biota akuatik akan terganggu (Manik, 2003). Sebagian besar biota akuatik sensitif terhadap perubahan $\mathrm{pH}$ dan menyukai nilai $\mathrm{pH}$ sekitar 7-8,5 (Effendi, 2003). Perubahan nilai $\mathrm{pH}$ dipengaruhi oleh masukan limbah pertanian, limbah domestik (deterjen).

\section{Salinitas}

Nilai salinitas sesuai dengan pernyatan Effendie (2003), nilai salinitas perairan tawar biasanya kurang dari $0,5 \%$, perairan payau antara $0,5 \%$ - $30 \%$ dan perairan laut $30 \%-40 \%$.

\section{Oksigen Terlarut}

Nilai DO bervariatif Oksigen terlarut dalam air sangat penting untuk menunjang kehidupan ikan dan organisme air lainya. Kemampuan air untuk membersihkan pencemaran secara alamiah banyak tergantung pada cukup tidaknya kadar oksigen terlarut. Penghilangan oksigen dalam perairan lebih banyak disebabkan oleh proses dekomposisi bahan organik yang membutuhkan oksigen terlarut. Keadaan perairan dengan kadar oksigen yang sangat rendah berbahaya bagi organisme akuatik. Semakin rendah kadar DO, akan meningkatkan daya toksisitas dari logam berat. Menurut Effendi (2003), bahwa DO yang kurang dari 1,0 $5,0 \mathrm{mg} /$ liter menimbulkan efek yang kurang menguntungkan bagi hampir semua organisme akuatik, biota dapat bertahan hidup tetapi pertumbuhannya terganggu.

\section{Evaluasi Data Regresi}

Dari hasil analisis statistik dapat dilihat nilai koefisien regresi antara regresi konsentrasi deterjen dalam sedimen dengan indeks kelimpahan relatif (KR) yaitu sebagai berikut:

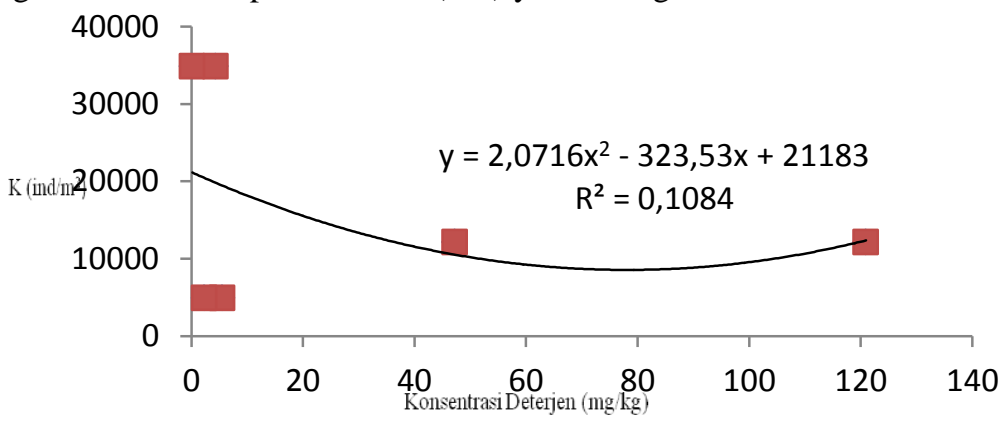

Gambar 4. Grafik Hubungan Konsetrasi Deterjen dalam Sedimen dengan Kelimpahan individu Sampling I

Dari gambar sampling I terlihat bahwa keeratan Kelimpahan individu (K) dan konsentrasi deterjen dalam sedimen adalah 0,33 termasuk pada kategori rendah jadi korelasi antara kelimpahan individu (K) terhadap konsentrasi deterjen dalam sedimen rendah atau peningkatan kelimpahan individu (K) dipengaruhi oleh konsentrasi deterjen rendah kemudian koefisisen determinasi sebesar 0,1084 artinya sebanyak 10,8\% perubahan Kelimpahan relatif dipengaruhi oleh deterjen, sedangkan sisanya 89,2\% merupakan faktor lain diluar variabel bebas sisanya. Hasil diferensiasi menghasilkan x sebesar 156,17 artinya nilai kelimpahan individu (K) minimum didapat saat $\mathrm{x}=156,17$ persamaan kuadratik awal maka di dapat $\mathrm{y}=21181,8$ artinya pada konsentrasi deterjen 156,17 mencapai nilai minimum kelimpahan individu (K) sebesar 21181,8.

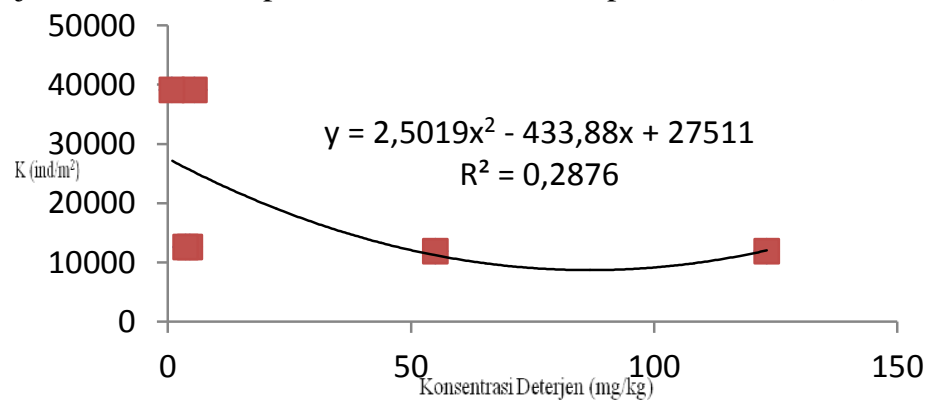

Gambar 5. Grafik Hubungan Konsetrasi Deterjen dalam Sedimen dengan Kelimpahan individu Sampling II

Dari gambar sampling II terlihat bahwa keeratan Kelimpahan individu (K) dan konsentrasi deterjen dalam sedimen adalah 0,54 termasuk pada kategori cukup jadi korelasi antara kelimpahan individu (K) terhadap konsentrasi deterjen dalam sedimen rendah atau peningkatan kelimpahan individu (K) dipengaruhi oleh konsentrasi deterjen rendah kemudian koefisisen determinasi sebesar 0,2876 artinya sebanyak $28,7 \%$ 
perubahan Kelimpahan relatif dipengaruhi oleh deterjen, sedangkan sisanya 7,13\% merupakan faktor lain diluar variabel bebas sisanya. Hasil diferensiasi menghasilkan x sebesar 173,4 artinya nilai kelimpahan individu $(\mathrm{K})$ minimum didapat saat $\mathrm{x}=173,4$ persamaan kuadratik awal maka di dapat $\mathrm{y}=27502,6$ artinya pada konsentrasi deterjen 173,4 mencapai nilai minimum kelimpahan individu (K) sebesar 27502,6.

\section{Konsentrasi Deterjen pada Sedimen}

Stasiun 1 (upper stream) diduga lokasi ini terdapat sumber pencemar masuk yang tidak terlihat atau tidak diketahui secara (fisik) pasti buanganya. Deterjen sebagai sumber polutan tersebut termasuk dalam kategori sumber tidak tentu (nonpoint source), yaitu sumber pencemaran yang tidak dapat diketahui secara pasti keberadaannya misalnya buangan yang berasal dari rumah tangga, pertanian, sedimentasi dan bahan pencemar lain yang sulit dilacak surnbernya (ARMS, 1990 dalam Susana dan Suyarso, 2008). Seperti halnya stasiun 1 pengulangan pertama sampling I dan II nilai konsetrasi deterjen 4,35 mg/kg dan 5,53 mg/kg yang merupakan nilai konsentrasi deterjen yang cukup tinggi. Stasiun 1 pengulangan kedua sampling I dan II nilai konsentrasi deterjen $0,18 \mathrm{mg} / \mathrm{kg}$ dan $0,89 \mathrm{mg} / \mathrm{kg}$ merupakan stasiun pengulangan yang paling rendah.

Stasiun 3 (lower stream) merupakan stasiun penelitian yang berada pada hilir sungai atau di muara dengan konsentrasi deterjen dalam sedimen $5,50 \mathrm{mg} / \mathrm{kg}$ dan $4,54 \mathrm{mg} / \mathrm{kg}$ angka ini masih lumayan tinggi karena merupakan lintasan pertama dari buangan limbah deterjen sehingga memungkinkan masih mempengaruhi nilai konsentrasi deterjen dalam sedimen. Stasiun 3 pengulangan 2 sampling I dan II yaitu $2,30 \mathrm{mg} / \mathrm{kg}$ dan 3,68 mg/kg masih meningkat pada sampling ke II.

Stasiun 4 atau stasiun yang berlokasi di laut ini memang sengaja pengambilan sampel tidak dilakukan pengulangan sampai dua kali, akan tetapi hanya diambil satu pengulangan dengan dua kali sampling dengan maksud hanya ingin diketahui apakah distribusi deterjen menyebar ke laut. Hasil pengamatan menunjukan nilai konsentrasi deterjen yang sedikit dibanding stasiun lainnya yaitu pada sampling I dan II adalah 0,02 $\mathrm{mg} / \mathrm{kg}$ dan $0,96 \mathrm{mg} / \mathrm{kg}$. Nilai konsentrasi deterjen ini menunjukan semakin berkurangnya konsentrasi deterjen menuju laut. Penyebaran konsentrasi deterjen ini umumnya menunjukan variasi konsentrasi yang semakin berkurang dengan semakin jauhnya jarak dari kondisi sungai yang tercemar buangan deterjen. Kondisi yang sama juga terjadi pada deterjen. Buangan deterjen yang terakumulasi di sedimen menyebar kearah sungai menuju pantai dan selanjutnya dilaut dengan konsentrasi deterjen yang semakin berkurang. Secara umum, pasokan bahan pencemar yang masuk ke dalam perairan laut berasal dari industri dan domestik melalui aliran sungai, kemudian mengalir ke dalam lingkungan laut melalui pengadukan atau turbulensi dan arus laut (Dahuri dan Damar, 2006 dalam Susana dan Suyarso, 2008). Untuk wilayah-wilayah laut yang luas dan terbuka, bahan pencemar ini akan terurai dan terbuang ke perairan laut yang lebih luas sehingga dapat meminimalkan konsentrasi alkumulasinya dalam suatu badan perairan (Susana dan Suyarso, 2008).

Peningkatan konsentrasi deterjen terjadi peningkatan pada sampling II hal ini diduga bahwa seiring meningkatnya hari meningkatnya produksi penggunaan deterjen pada saat sampling ke II penggunaan deterjen yang berlebihan sehingga semakin meningkat konsentrasi deterjen yang terakumulasi dalam sedimen.

\section{Struktur Komunitas Makrozoobentos \\ Kepadatan dan Kelimpahan Relatif (KR)}

Berdasarkan kepadatan makrozoobentos pada masing-masing stasiun didapatkan kepadatan tertinggi pada stasiun 1 sampling I dan II sebesar $36740.74 \mathrm{ind} / \mathrm{m}^{2}$ dan kepadatan terendah $1,19.75309$ ind $/ \mathrm{m}^{2}$. Berdasarkan pengamatan diperoleh data untuk stasiun 1 sampling I yaitu Terebralia palustris $87 \%$, sampling II Terebralia palustris 94\%. Kelimpahan relatif tertinggi adalah Terebralia palustris sebesar dan terendah sampling I Capitellidae 0\% sampling ke II Nereidae 0\%. Kelimpahan relatif tertinggi adalah Terebralia palustris sebesar 49\%. Terebralia palustris memang banyak ditemui di stasiun ini karena spesies ini hidup dikandungan tanah yang kandungan organiknya tinggi (Ollafsson dan Carlen, 2002). Menurut Wirjodihardjo dalam Sutedjo dan Kartasapoetra (2002), bahwa intensitas warna tanah dipengaruhi tiga faktor yaitu jenis mineral dan jumlahnya, kandungan bahan organik tanah dan kadar air tanah dan tingkat hidratasi. Kondisi ini sama dengan tanah stasiun 1 berwarna gelap sehingga dapat diartikan makin tinggi kandungan bahan organik maka warna tanah makin gelap (kelam) dan sebaliknya makin sedikit kandungan bahan organik tanah maka warna tanah akan tampak lebih terang. Kemudian Terebralia palustris merupakan spesies yang perkembang biakannya cepat (Ollafsson dan Carlen, 2002), sehingga spesies ini tidak mengherankan ditemukan cukup melimpah di stasiun 1 .

Pengamatan stasiun 2 Kelimpahan tertinggi masih sama dengan stasiun 1 yaitu Terebralia palustris, spesies ini melimpah juga distasiun ini, ditandai dengan warna tanah yang hitam pekat dan berbau menunjukan tanah tersebut mengandung bahan organik tinggi, bahan organik ini bermacam-macam sumbernya terutama paling banyak sampah organik karena letaknya yang banyak ditumbuhi tanamantanaman dan stasiun ini merupakan stasiun yang diambil karena terdapat pembuangan limbah deterjen.

Stasiun $3 T$. palustris adalah satu-satunya biota yang memakan (konsumen) daun mampu mencari makanan di bawah air selama pasang tinggi dan bertanggung jawab untuk menghilangkan sejumlah besar sampah mangrove (Ollafsson dan Carlen, 2002), Jadi cocok sekali spesies ini tinggi kelimpahanya dibanding spesies lain karena habitat yang mendukung. 
Kelimpahan relatif stasiun 4 sampling I atau laut ini dari kelas Bivalvia yaitu Kelimpahan tertinggi adalah Tellina palatam atau sebuah kerang filter ditemukan di pasir berlumpur di kedalaman 2-3 m (Kay, 1979 dalam Dye, 1994). Kondisi sedimen saat sampling pertama ditemukan di lokasi ini pasir berlumpur disebabkan lokasi yang tidak jauh juga dengan muara sehingga masih dipengaruhi lumpur yang masuk ke lokasi ini. Sampling II kelimpahan relatif tertinggi Rhinoclavis $s p$.

\section{Indeks Keanekaragaman $\left(\mathbf{H}^{\prime}\right)$}

Pengamatan nilai indeks keanekaragaman ( $\left.\mathrm{H}^{\prime}\right)$ cenderung lebih tinggi dalam komunitas yang lebih tua dibanding komunitas yang baru.

\section{Indeks Keseragaman (E)}

Nilai Keseragaman (E) tertinggi pada stasiun 4 sampling II, sedang nilai keseragaman terendah pada stasiun 1 sampling II. Hal ini sesuai dengan pernyataan Hartati dan Awwaluddin (2007) dalam Jauhara (2012), bahwa semakin besar nilai keseragaman menunjukkan keseragaman jenis yang besar, artinya kepadatan tiap jenis dapat dikatakan sama dan cenderung tidak didominasi oleh jenis tertentu, sebaliknya semakin kecil nilai keseragaman menunjukkan keseragaman jenis yang kecil, artinya kepadatan tiap jenis dapat dikatakan tidak sama dan cenderung didominasi oleh jenis tertentu. Lebih lanjut Hartati dan Awwaluddin (2007) dalam Jauhara (2012), menjelaskan bahwa tingginya nilai keseragaman disebabkan oleh perbedaan jenis dan jumlah individu yang seimbang.

\section{Indeks Dominasi (D)}

Hal inilah yang membuat jenis Terebralia palustris kelas gastropoda mendominasi di perairan. Adanya dominasi oleh spesies tertentu dikarenakan tidak dapat berdaptasinya suatu spesies yang lainnya terhadap lingkungan tempat hidupnya terhadap suatu lingkungan. Hal ini menunjukkan adanya dominasi oleh spesies tertentu pada perairan tersebut. spesies ini hidup pada sedimen yang mempunyai kandungan organik tinggi dan sering ditemui dikawasan yang ditumbuhi mangrove. Perairan sungai sayung ini salah satunya muara yang ditumbuhi mangrove, sehingga spesies ini juga ditemukan disini. Akan tetapi di stasiun 4 laut tidak ditemukan spesies ini.

\section{Hubungan Konsentrasi Deterjen didalam Sedimen dengan Kelimpahan Individu}

Konsentrasi deterjen yang berlebihan akan menggangu keberadaan biota perairan atau makrozoobentos baik kelimpahan, keanekaragaman,keseragaman jenis dan dominasi. Dari hasil regresi diperoleh bahwanya kelimpahan individu akan semakin berkurang dengan tingginya nilai konsentrasi deterjen. Semakin tinggi nilai konsentrasi deterjen semakin sedikit spesies makrozoobentos yang mampu bertahan hidup. Saat sampling I hubungan konsentrasi deterjen dengan kelimpahan individu rendah, sedang saat sampling II yaitu pada saat pasang menunjukkan hubungan konsentrasi deterjen dengan kelimpahan individu cukup. Ini menunjukan bahwa pada saat pasang deterjen mempunyai keeratan yag lebih dibanding waktu surut karena faktor lain salah satunya arus juga mempengaruhi. Spesies yang mampu bertahan pada konsentrasi deterjen di stasiun 2 (middle stream) yaitu Tereberalia palustris dan Faunus ater. Selanjutnya dari hasil identifikasi makrozoobentos terungkap bahwa pada stasiun 2 mengalami kelimpahan yang tinggi yaitu 98\% di tempati oleh spesies Terebralia palustris, spesies ini kemungkinan dicemari oleh tingkat pencemaran organik yang tinggi terlihat dari warna sedimen yang hitam pekat saat diambil sampelnya menandakan bahwa di dalam sedimen kandungan organik tinggi karena deterjen mengandung posfat, poliposfat dari deterjen ini diperkirakan memberikan konstribusi 50\% dari seluruh posfat yang ada diperairan (Effendi, 2003), sehingga dapat juga menyebabkan eutrofikasi (pengkayaan).

\section{Kesimpulan}

Berdasarkan hasil penelitian yang telah dilakukan dapat diambil kesimpulan sebagai berikut :

1. Konsentrasi deterjen di Sungai Sayung kandungan meningkat $0,02 \mathrm{mg} / \mathrm{kg}-123,17 \mathrm{mg} / \mathrm{kg}$.

2. Kelimpahan Relatif makrozoobentos di sungai Sayung berkisar $43 \%$ - 98\%. Indeks Keanekaragaman berkisar $0,14-1,49$.

3. Konsentrasi deterjen yang berlebihan akan menganggu kelimpahan individu makrozoobentos, semakin tinggi konsentrasi semakin sedikit spesies yang mampu bertahan.

4. Sedimen sungai Sayung tercemar oleh deterjen, struktur komunitas makrozoobentos dengan melihat indeks keanekaragaman berkisar 0,14 - 1,49 yang menunjukkan bahwa kemampuan perairan sungai Sayung untuk mendukung kelangsungan hidup makrozoobentos tergolong rendah dan dilihat kondisi kestabilan suatu komunitas dalam keadaan tidak stabil.

\section{Ucapan Terima Kasih}

Ucapan terima kasih ditujukan pula kepada Dr. Ir. Haeruddin, M.Si dan Dr. Ir. Pujiono Wahyu Purnomo, MS atas bimbingannya dalam penyusunan penelitian ini. 


\section{Daftar Pustaka}

APHA, 1992. (American Public Health Association): Standard Method for The Examination of Water and Wastewater 19th ed., AWWA (American Water Works Association), and WPCF (Water Pollution Control Federation). Washington D. C.

Brower, J.E. dan J.H Zar. 1989. Field and Laboratory Methods for General Ecology. W. M. Brown Company Publ. Dubuque Lowa.

Connell, D. W. dan GJ Miller. 1995. Kimia dan Ekotoksikologi Pencemaran. UI Press. Jakarta.

Darmono, 2001. Lingkungan Hidup dan Pencemaran: hubungannya dengan toksikologi senyawa logam.UI Press. Jakarta. Dean AM, H Simon, G Wade, T Olivier, S Aneeqa, D Duncan, B Thomas. 2007.

Dharma B. 1988. Siput dan Kerang Indonesia (Indonesian Shells). Jakarta: PT. Sarana Graha. 1992. Indonesian Shells II. Jakarta: PT. Sarana Graha.

Dye, T. 1994. Apparent Ages Of Marine Shells: Implications For Archaeological Dating In Hawai. State of Hawaii, Department of Land and Natural Resources, Historic Preservation Division. [Radiocarbon, VoL. 36, No. 1, 1994, P. 51-57].

Effendi, H. 2003. Telaah Kualitas Air Bagi Pengelolaan Sumber Daya dan Lingkungan Perairan. Kanisius: Yogyakarta.

Haeruddin, Djuwito, dan Afiati, N. 2007. Mata Kuliah Avertebrata Air. Program Studi Manajemen Sumberdaya Perairan FPIK. UNDIP: Semarang.

Jauhara, A. 2012. Stuktur Komunitas Polychaeta pada Lima Muara Sungai di Teluk Jakarta. [skripsi]. Fakultas Matematika dan Ilmu Alam Dapertemen Biologi Depok.

Juandi, M. 2011. Penyelidikan Pola Sebaran Limbah Deterjen Bawah Permukaan Tanah dengan Aplikasi Geolistrik. Jurnal Lingkungan. FMIPA Universitas Riau.

Kartasapoetra, A. G. dan M. M. Sutedjo. 1987. Teknologi Konservasi Tanah dan Air. Rineka Cipta: Jakarta.

Krebs, C. J. 1972. Ecological Methodology. Harper Collins Publishers.

Manik, K. E. S. 2003. Pengelolaan Lingkungan Hidup. Penerbit Djambatan: Jakarta.

Nugrah, K. P. 2008. Struktur Komunitas Meibenthos yang Dikaitkan dengan Tingkat Pencemaran Sungai Jerambah dan Sungai Buding. Kepulauan Bangka Belitung. [skripsi]. Dapertemen Manajemen Sumberdaya Perairan Fakultas Perikanan dan Ilmu Kelautan Institut Pertanian Bogor: Bogor.

Odum, E. 1971. Fundamentals of Ecology $3^{\text {rd }}$ ed. Saunders Company Philadelphia: London, Toronto.

Ollafsson dan Carlen, 2002. The effects of the gastropod Terebralia palustris on infaunal communities in a tropical tidal mud-flat in East Africa. [Wetlands Ecology an Management 10:303-311, 2002]. Kluwer Academic Publishers, Printed in the Netherlands. Dapertment of Zoology, Unyversity of Stockholm, Sweden.

Reid, D. 2000. Large juveniles and adults of Terebralia palustris feeding on a fallen mangrove leaf, near Pemba, Mozambique. Natural History Museum: London.

Sudjana, 1992. Teknik Analisis Regresi dan Korelasi. Tarsito: Bandung.

Sugiono, 2005. Metode Penelitian. Bandung : Alfabeta.

Susana, T. 1996. Perkiraan kadar fosfat dalam perairan yang mengandung limbah deterjen. Dalam : D.P. Praseno, W. S. Atmadja, I. Supangat, Ruyitno, B.S. Soedibjo (eds.). Inventarisasi cicln evaluasi lingkungan pesisir: Oseanografi, geologi, biologi dan ekologi. Pusat Penelitian Pengembangan Oseanologi. LIPI. Jakarta: 1-9.

Susana, T. dan Suyarso. 2008. Penyebaran Fosfat dan Deterjen di Perairan Pesisir dan Laut sekitar Cirebon, Jawa Barat. Pusat Penelitian Oseanografi - LIPI. Oseanologi dm Limnologi di Indonesia (2008) 34: 117-131. Received 29 January 2008, Accepted 16 April 2008.

Wilhm, JF. 1975. Biological Indicator of Pollution. Di dalam Whitton BA, editor. River Ecology. London: Blackwell Scientific Publications.

Zulfiandi, Zinuri, H. 2012. Struktur Komunitas Makrozoobentos di Perairan Pandansari Kecamatan Sayung Kabupaten Demak. Journal of Marine Research. Volume 1, Nomor 1, Tahun 2012, Halaman 62-66. Online di: http://ejournal-sl.undip.ac.id/index.php/jmr. Jurusan Ilmu Kelautan, Fakultas Perikanan dan Ilmu Kelautan, Universitas Diponegoro. 